\title{
Clinical practice recommendations for quality of life assessment in patients with gynecological cancer
}

\author{
Wojciech Leppert ${ }^{1}$, Leszek Gottwald ${ }^{2}$, Maria Forycka ${ }^{3}$ \\ ${ }^{1}$ Chair and Department of Palliative Medicine, Poznan University of Medical Sciences, Poznan, Poland \\ ${ }^{2}$ Department of Radiotherapy, Medical University, Łodz, Poland \\ ${ }^{3}$ Department of Vascular Diseases of the Nervous System and Neurology, Ministry of Internal Affairs Hospital, Poznan, Poland
}

\begin{abstract}
Quality of life (QoL) is a multidimensional concept regarding self-assessment of patients' situation. Quality of life has not been clearly defined up to date, although it is clear that it is a subjective self-assessment that to a significant extent is determined by individual needs, beliefs, values, attitudes, which are changing with time. Health-related QoL comprises basic dimensions such as patients' performance status, physical, emotional, and social functioning, symptoms of the disease and adverse effects of treatment, spiritual (God and existential) and other dimensions.

In women, the ovary, cervical, corpus uterus, vagina and vulva cancers deteriorate QoL by disease progression and consequences of treatment, also in cancer survivors. Common symptoms include the genito-urinary system, the lower gastrointestinal tract and peripheral neuropathies induced by chemotherapy. In young women, QoL is impaired by infertility, sexual problems and menopause symptoms.

An overview of QoL questionnaires used in oncology with special regard to patients with gynecological tumors was conducted. A screening tool for psychological state assessment of oncology patients (distress thermometer), the Edmonton Symptom Assessment System (ESAS) and modular approach of QoL assessment recommended by the EORTC (European Organization for the Research and Treatment of Cancer) were presented. Practical guidelines were proposed to assess appropriately QoL in patients with gynecological cancers who stay at in-patient gynecology units and those treated at home and in an ambulatory care setting.
\end{abstract}

Key words: gynecological cancer, oncology, quality of life, supportive care, symptoms.

\section{Introduction}

Quality of life (QoL) has not been clearly defined up to date, although it is clear that it is a subjective self-assessment that to a significant extent is determined by individual needs, beliefs, values, attitudes, which are changing with time. In medical sciences, Schipper has introduced a concept of a health-related QoL [1]. QoL comprises basic dimensions such as patients' performance status, physical, emotional, and social functioning, symptoms of the disease and adverse effects (AE) of the treatment. QoL refers also to spiritual (existential and God) and other dimensions, for example body image changes. In the general QoL assessment that is determined by the health status, apart from the symptoms of the disease and AE of the treatment, the attitude of patients to themselves, their own disease and ways of coping with the disease are taken into account [2].

When evaluating QoL special attention is paid to the necessity to differentiate between an objective assessment of the health status (clinical staging, diagnosis, symptom intensity, limitations in physical and social functioning due to the disease) and a subjective QoL assessment. The subject of QoL is not an objective evaluation of the disease status but a subjective patients' self-assessment of their life [3-6]. QoL evaluation is normally conducted subjectively, from the patients' perspective. If patients cannot assess their QoL, then proxies (physicians, nurses, carers) may do that. QoL evaluation has a positive impact on the patients, families and carers' well-being and also improves patients' satisfaction from care provided and improves the process of the adaptation to a disease. 
Factors influencing quality of life of women with different localization of gynecological cancer

\section{Tumors of the ovary and oviduct}

The main method of the management of ovary and oviduct tumors is surgical intervention and systemic treatment, which significantly influence women's QoL. A surgical intervention comprises resection of the uterus, both ovaries, greater omentum, appendix and local lymph nodes, and in the case of an unresectable tumor, a maximal cytoreduction is conducted $[7,8]$. After ovariectomy in premenopausal women, QoL is significantly deteriorated by infertility and a sudden appearance of menopausal symptoms due to the decrease in the level of sex hormones in the blood serum, predominantly estrogens. The intensity of menopausal symptoms is different depending on the individual patient but in most cases it significantly decreases a sense of well-being. Apart from subjective symptoms, menopause objectively disturbs bone and vessel wall metabolism, which increases the risk of osteoporosis development and possibility of bone fractures and vascular episodes, which may all significantly deteriorate QoL [9].

The systemic treatment (most commonly chemotherapy with platinum derivatives and taxanes) may induce nausea, vomiting, lack of appetite, alopecia, weakness and fatigue. In spite of the burden and the need of symptom prevention, the symptoms usually disappear within a few days after treatment completion. Symptoms of peripheral polyneuropathies may be more problematic in terms of management and more sustainable. Such symptoms appear during treatment with platinum derivatives and taxanes.

Fig. 1. The distress thermometer

Please circle one number (0-10), which in the best way depicts how much distress you felt during the last week excluding today

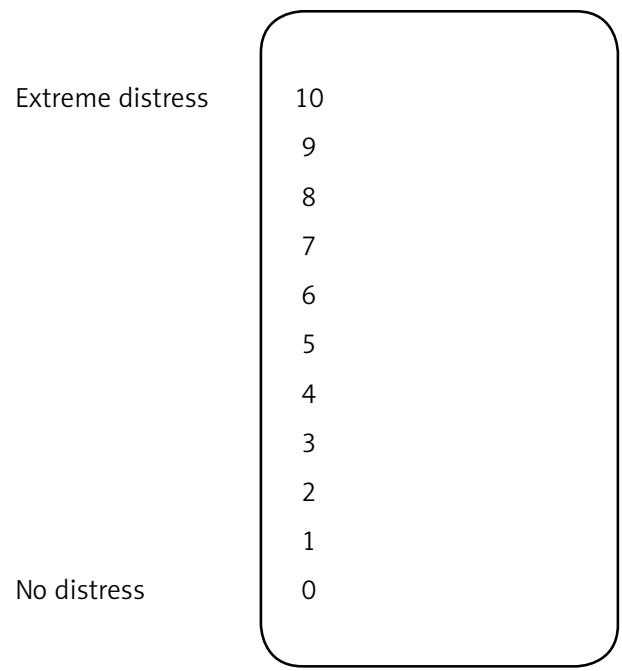

The most common symptoms in the advanced phase of ovary and oviduct cancer are as follows: ascites, abdominal and hypogastric pain often associated with the dissemination of the tumor in the abdomen. Apart from colicky pain, other symptoms comprise nausea and vomiting, difficulties in food consumption, constipation, weakness and fatigue, which may accompany the anorexia-cachexia-asthenia syndrome. The listed symptoms may intensify significantly in patients with bowel obstruction [10].

\section{Tumors of uterus cervix and corpus}

The management of cervix and corpus uterus cancer is based usually on surgical interventions and radiotherapy and the observed AE are associated with the type of the treatment applied. In patients classified as IA according to FIGO (Féderation Internationale de Gynécologie et d'Obstétrique) with a well-differentiated tumor of uterus corpus type I (endometrioid adenocarcinoma) and in cases of squamous cell cancer $\mathrm{G} 1$ of the cervical cancer stage 0-IA, a surgical intervention is recommended and the observed QoL deterioration is relatively the least intense and usually a short-term phenomenon. In the rest of patients the possibility of both short- and long-term QoL deterioration is much bigger due to radiotherapy and/or chemotherapy. In cervix and corpus uterus cancer patients, most commonly adjuvant radiotherapy after surgery is administered and in the group of patients with endometrium cancer type II (non-endometrioid) systemic treatment is applied.

In patients with locally advanced cervical cancer (IIB-IIIB), the management of choice is radio-chemotherapy with platinum derivatives. In cervical and uterine corpus cancer stage IV, in whom QoL deterioration is induced by symptoms of tumor progression, the treatment is planned individually depending on the clinical situation [11-14].

In the case of surgical intervention, urine incontinence and other urinary system disturbances and sexual dysfunction may appear [15]. Radiotherapy complications comprise changes in vaginal mucosa that may induce dyspareunia and make sexual activity difficult. Radiotherapy may induce adhesions, damage to the rectal and vagina mucosa, urinary symptoms and sexual problems. In consequence of radiotherapy, pain in the rectum intensifies during bowel movement, bowel dysfunction associated with a dissemination of cancer in the abdomen may lead to intestinal obstruction which demand surgical intervention. In a small percentage of patients undergoing radical radiotherapy, the complication of the treatment is development of fistulae in the pelvis, most commonly vesicovaginal or recto-vaginal fistula, which dramatically deteriorate QoL in patients with advanced cervical cancer. In the case of recto-vaginal fistula, in most patients the treatment of choice 
is colostomy development, which may also additionally deteriorate QoL [16].

In the advanced period of the disease the most common symptoms of uterus tumors comprise pain in the hypogastrium usually associated with a local cancer progression in the pelvis and abdomen. Often, there are symptoms of neuropathic pain associated with the infiltration of nervous plexus. The development of cancer may be accompanied by several symptoms such as nausea, vomiting, lack of appetite, constipation, weakness, fatigue and cachexia. In patients with locally advanced cervical cancer, renal insufficiency may develop and it may be necessary to conduct nephrostomy for urine outflow. The symptom of a tumor development might be also colporrhagia, which in the case of endometrium cancer usually proceeds to cause other symptoms. In patients with squamous cell carcinoma, symptoms are rarely associated with distant metastases; it is typical of sarcoma that often metastasizes to lungs and induces dyspnea or other symptoms depending on the location.

\section{Tumors of vagina and vulva}

Due to the location of the tumor pain, problems with passing urine and sexual functioning may be present. It is not uncommon that intractable pruritus appears in spite of the treatment used. The management of vaginal cancer is mainly composed of radiotherapy, only in selected patients surgical intervention is conducted [17]. In patients with vulva cancer the basic approach is surgery with adjuvant radiotherapy in some patients treated [18]. In advanced stages of vagina and vulva cancer, a systemic treatment may also be applied. The treatment of vaginal and particularly vulva cancer is often associated with a significant damage that strongly deteriorates patients' QoL.

In the case of a diagnosis of a gynecological cancer in women, one should always take into account a negative impact of the disease on the emotional, social and spiritual functioning. This requires the staff caring for patients with gynecological cancer not only to provide

Fig. 2. Questions for patients with a score of 5 or more on the distress thermometer

Please indicate which item from the list was a problem for you last week, including today. Please make sure that you marked YES or NO in each item.

\begin{tabular}{|c|c|c|c|c|c|}
\hline Yes & No & Practical problems & Yes & No & Physical problems \\
\hline$\square$ & $\square$ & Bringing up a child & $\square$ & $\square$ & Image \\
\hline$\square$ & $\square$ & Flat & $\square$ & $\square$ & Washing/dressing \\
\hline$\square$ & $\square$ & Insurance/finances & $\square$ & $\square$ & Breathing \\
\hline$\square$ & $\square$ & Transport/local public transport & $\square$ & $\square$ & Changes in passing urine \\
\hline$\square$ & $\square$ & Work/school & $\square$ & $\square$ & Constipation \\
\hline$\square$ & $\square$ & Family problems & $\square$ & $\square$ & Diarrhea \\
\hline$\square$ & $\square$ & Relationship with children & $\square$ & $\square$ & Food consumption \\
\hline \multirow[t]{2}{*}{$\square$} & $\square$ & Relationship with a partner & $\square$ & $\square$ & Fatigue \\
\hline & & Emotional problems & $\square$ & $\square$ & Feeling edema \\
\hline$\square$ & $\square$ & Depression & $\square$ & $\square$ & Fever \\
\hline$\square$ & $\square$ & Anxiety & $\square$ & $\square$ & Moving \\
\hline$\square$ & $\square$ & Nervousness & $\square$ & $\square$ & Dyspepsia \\
\hline$\square$ & $\square$ & Sadness & $\square$ & $\square$ & Memory/concentration \\
\hline$\square$ & $\square$ & Worrying & $\square$ & $\square$ & Changes in the mouth \\
\hline$\square$ & $\square$ & Losing interest in everyday activities & $\square$ & $\square$ & Nausea \\
\hline \multirow[t]{3}{*}{$\square$} & $\square$ & Religious/spiritual issues & $\square$ & $\square$ & Dryness in the nose or excessive sputum \\
\hline & & & $\square$ & $\square$ & Pain \\
\hline & & & $\square$ & $\square$ & Sexuality \\
\hline \multicolumn{3}{|c|}{ Other problems....... } & $\square$ & $\square$ & Dry skin \\
\hline \multicolumn{3}{|c|}{ (1) } & $\square$ & $\square$ & Sleep \\
\hline \multicolumn{3}{|c|}{ 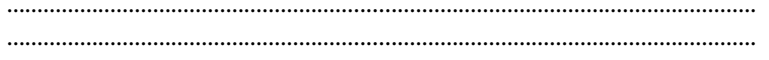 } & $\square$ & $\square$ & Tingling in hands/feet \\
\hline
\end{tabular}


Fig. 3. The Modified Hospital Anxiety and Depression Scale (HADS)

Tick the box beside the reply that is closest to how you have been feeling in the past week.

Don't take too long over your replies: your immediate reaction is the best.

\begin{tabular}{|c|c|c|c|c|c|}
\hline D & A & & D & A & \\
\hline & & I feel tense or 'wound up': & & & I feel as if I am slowed down: \\
\hline & 3 & Most of the time & 3 & & Nearly all the time \\
\hline & 2 & A lot of the time & 2 & & Very often \\
\hline & 1 & From time to time, occasionally & 1 & & Sometimes \\
\hline & \multirow[t]{2}{*}{0} & Not at all & 0 & & Not at all \\
\hline & & I still enjoy the things I used to enjoy: & & & $\begin{array}{l}\text { I get a sort of frightened feeling like 'butterflies' } \\
\text { in the stomach: }\end{array}$ \\
\hline 0 & & Definitely as much & & 0 & Not at all \\
\hline 1 & & Not quite so much & & 1 & Occasionally \\
\hline 2 & & Only a little & & 2 & Quite often \\
\hline \multirow[t]{7}{*}{3} & & Hardly at all & & 3 & Very often \\
\hline & & $\begin{array}{l}\text { I get a sort of frightened feeling as if something } \\
\text { awful is about to happen: }\end{array}$ & & & I have lost interest in my appearance: \\
\hline & 3 & Very definitely and quite badly & 3 & & Definitely \\
\hline & 2 & Yes, but not too badly & 2 & & I don't take as much care as I should \\
\hline & 1 & A little, but it doesn't worry me & 1 & & I may not take quite as much care \\
\hline & \multirow[t]{2}{*}{0} & Not at all & 0 & & I take just as much care as ever \\
\hline & & I can laugh and see the funny side of things: & & & I feel restless as I have to be on the move: \\
\hline 0 & & As much as I always could & & 3 & Very much indeed \\
\hline 1 & & Not quite so much now & & 2 & Quite a lot \\
\hline 2 & & Definitely not so much now & & 1 & Not very much \\
\hline \multirow[t]{7}{*}{3} & & Not at all & & 0 & Not at all \\
\hline & & Worrying thoughts go through my mind: & & & I look forward with enjoyment to things: \\
\hline & 3 & A great deal of the time & 0 & & As much as I ever did \\
\hline & 2 & A lot of the time & 1 & & Rather less than I used to \\
\hline & 1 & From time to time, but not too often & 2 & & Definitely less than I used to \\
\hline & \multirow[t]{2}{*}{0} & Only occasionally & 3 & & Hardly at all \\
\hline & & I feel cheerful: & & & I get sudden feelings of panic: \\
\hline 3 & & Not at all & & 3 & Very often indeed \\
\hline 2 & & Not often & & 2 & Quite often \\
\hline 1 & & Sometimes & & 1 & Not very often \\
\hline \multirow[t]{11}{*}{0} & & Most of the time & & 0 & Not at all \\
\hline & & I can sit at ease and feel relaxed: & & & I can enjoy a good book or radio or TV program: \\
\hline & 0 & Definitely & 0 & & Often \\
\hline & 1 & Usually & 1 & & Sometimes \\
\hline & 2 & Not often & 2 & & Not often \\
\hline & 3 & Not at all & 3 & & Very seldom \\
\hline & $\mathrm{R}$ & I had bursts of anger: & $\mathrm{R}$ & & I was nervous and angry: \\
\hline & 3 & Often & 3 & & Often \\
\hline & 2 & Sometimes & 2 & & Sometimes \\
\hline & 1 & Seldom & 1 & & Seldom \\
\hline & 0 & Not at all & 0 & & Not at all \\
\hline
\end{tabular}

Please check you have answered all the questions

Scoring:

Total score: Depression (D)

Anxiety (A)

Anger (R)

0-7 $=$ Normal; 8-10 = Borderline abnormal (borderline case); $11-21=$ Abnormal (case) 
Fig. 4. The EORTC QLQ-C30 (version 3)

We are interested in some things about you and your health. Please answer all of the questions yourself by circling the number that best applies to you. There are no "right" or "wrong" answers. The information that you provide will remain strictly confidential. Please fill in your initials:

Your birthdate (Day, Month, Year):

Today's date (Day, Month, Year):

\begin{tabular}{|c|c|c|c|c|}
\hline & $\begin{array}{l}\text { Not at } \\
\text { all }\end{array}$ & $\begin{array}{c}\text { A } \\
\text { little }\end{array}$ & $\begin{array}{l}\text { Quite } \\
\text { a bit }\end{array}$ & $\begin{array}{l}\text { Very } \\
\text { much }\end{array}$ \\
\hline $\begin{array}{l}\text { 1. Do you have any trouble doing strenuous activities, like carrying a heavy shopping } \\
\text { bag or a suitcase? }\end{array}$ & 1 & 2 & 3 & 4 \\
\hline 2. Do you have any trouble taking a long walk? & 1 & 2 & 3 & 4 \\
\hline 3. Do you have any trouble taking a short walk outside of the house? & 1 & 2 & 3 & 4 \\
\hline 4. Do you need to stay in bed or a chair during the day? & 1 & 2 & 3 & 4 \\
\hline 5. Do you need help with eating, dressing, washing yourself or using the toilet? & 1 & 2 & 3 & 4 \\
\hline During the past week: & $\begin{array}{c}\text { Not at } \\
\text { all }\end{array}$ & $\begin{array}{c}\text { A } \\
\text { little }\end{array}$ & $\begin{array}{l}\text { Quite } \\
\text { a bit }\end{array}$ & $\begin{array}{l}\text { Very } \\
\text { much }\end{array}$ \\
\hline 6. Were you limited in doing either your work or other daily activities? & 1 & 2 & 3 & 4 \\
\hline 7. Were you limited in pursuing your hobbies or other leisure time activities? & 1 & 2 & 3 & 4 \\
\hline 8. Were you short of breath? & 1 & 2 & 3 & 4 \\
\hline 9. Have you had pain? & 1 & 2 & 3 & 4 \\
\hline 10. Did you need to rest? & 1 & 2 & 3 & 4 \\
\hline 11. Have you had trouble sleeping? & 1 & 2 & 3 & 4 \\
\hline 12. Have you felt weak? & 1 & 2 & 3 & 4 \\
\hline 13. Have you lacked appetite? & 1 & 2 & 3 & 4 \\
\hline 14. Have you felt nauseated? & 1 & 2 & 3 & 4 \\
\hline 15. Have you vomited? & 1 & 2 & 3 & 4 \\
\hline 16. Have you been constipated? & 1 & 2 & 3 & 4 \\
\hline During the past week: & $\begin{array}{l}\text { Not at } \\
\text { all }\end{array}$ & $\begin{array}{c}\text { A } \\
\text { little }\end{array}$ & $\begin{array}{l}\text { Quite } \\
\text { a bit }\end{array}$ & $\begin{array}{l}\text { Very } \\
\text { much }\end{array}$ \\
\hline 17. Have you had diarrhea? & 1 & 2 & 3 & 4 \\
\hline 18. Were you tired? & 1 & 2 & 3 & 4 \\
\hline 19. Did pain interfere with your daily activities? & 1 & 2 & 3 & 4 \\
\hline $\begin{array}{l}\text { 20. Have you had difficulty in concentrating on things, like reading a newspaper or } \\
\text { watching television? }\end{array}$ & 1 & 2 & 3 & 4 \\
\hline 21. Did you feel tense? & 1 & 2 & 3 & 4 \\
\hline 22. Did you worry? & 1 & 2 & 3 & 4 \\
\hline 23. Did you feel irritable? & 1 & 2 & 3 & 4 \\
\hline 24. Did you feel depressed? & 1 & 2 & 3 & 4 \\
\hline 25. Have you had difficulty remembering things? & 1 & 2 & 3 & 4 \\
\hline 26. Has your physical condition or medical treatment interfered with your family life? & 1 & 2 & 3 & 4 \\
\hline $\begin{array}{l}\text { 27. Has your physical condition or medical treatment interfered with your social activi- } \\
\text { ties? }\end{array}$ & 1 & 2 & 3 & 4 \\
\hline 28. Has your physical condition or medical treatment caused you financial difficulties? & 1 & 2 & 3 & 4 \\
\hline
\end{tabular}

\section{For the following questions, please circle the number between 1 and 7 that best applies to you}

29. How would you rate your overall health during the past week?

$\begin{array}{llllllll} & 1 & 2 & 3 & 4 & 5 & 6 & 7 \\ \text { Very poor } & & & & & & & \text { Excellent }\end{array}$

30. How would you rate your overall quality of life during the past week?

$\begin{array}{lllllll}1 & 2 & 3 & 4 & 5 & 6 & 7 \\ \text { Very poor } & & & & & & \end{array}$


Fig. 5. The EORTC QLQ-C15-PAL (version 1)

We are interested in some things about you and your health. Please answer all of the questions yourself by circling the number that best applies to you. There are no "right" or "wrong" answers. The information that you provide will remain strictly confidential. Please fill in your initials:

Your birthdate (Day, Month, Year):

Today's date (Day, Month, Year):

\begin{tabular}{|c|c|c|c|c|}
\hline & $\begin{array}{c}\text { Not at } \\
\text { all }\end{array}$ & $\begin{array}{c}\text { A } \\
\text { little }\end{array}$ & $\begin{array}{l}\text { Quite } \\
\text { a bit }\end{array}$ & $\begin{array}{l}\text { Very } \\
\text { much }\end{array}$ \\
\hline 1. Do you have any trouble taking a short walk outside of the house? & 1 & 2 & 3 & 4 \\
\hline 2. Do you need to stay in bed or a chair during the day? & 1 & 2 & 3 & 4 \\
\hline 3. Do you need help with eating, dressing, washing yourself or using the toilet? & 1 & 2 & 3 & 4 \\
\hline During the past week: & $\begin{array}{c}\text { Not at } \\
\text { all }\end{array}$ & $\begin{array}{c}\text { A } \\
\text { little }\end{array}$ & $\begin{array}{l}\text { Quite } \\
\text { a bit }\end{array}$ & $\begin{array}{l}\text { Very } \\
\text { much }\end{array}$ \\
\hline 4. Were you short of breath? & 1 & 2 & 3 & 4 \\
\hline 5. Have you had pain? & 1 & 2 & 3 & 4 \\
\hline 6. Have you had trouble sleeping? & 1 & 2 & 3 & 4 \\
\hline 7. Have you felt weak? & 1 & 2 & 3 & 4 \\
\hline 8. Have you lacked appetite? & 1 & 2 & 3 & 4 \\
\hline 9. Have you felt nauseated? & 1 & 2 & 3 & 4 \\
\hline During the past week: & $\begin{array}{c}\text { Not at } \\
\text { all }\end{array}$ & $\begin{array}{c}\text { A } \\
\text { little }\end{array}$ & $\begin{array}{l}\text { Quite } \\
\text { a bit }\end{array}$ & $\begin{array}{l}\text { Very } \\
\text { much }\end{array}$ \\
\hline 10. Have you been constipated? & 1 & 2 & 3 & 4 \\
\hline 11. Were you tired? & 1 & 2 & 3 & 4 \\
\hline 12. Did pain interfere with your daily activities? & 1 & 2 & 3 & 4 \\
\hline 13. Did you feel tense? & 1 & 2 & 3 & 4 \\
\hline 14. Did you feel depressed? & 1 & 2 & 3 & 4 \\
\hline
\end{tabular}

For the following question, please circle the number between 1 and 7 that best applies to you

15. How would you rate your overall quality of life during the past week?

$\begin{array}{llllllll} & 1 & 2 & 3 & 4 & 5 & 6 & 7 \\ \text { Very poor } & & & & & & & \end{array}$

appropriate medical (directed at the underlying disease and symptomatic) management of the disease but also comprehensive support in all patients' life dimensions. To achieve this aim it is necessary to use an interdisciplinary approach with the involvement of physicians, nurses, psychologists, social workers and volunteers and patients' families and carers.

\section{Clinical practice recommendations for quality of life assessment}

Intensive QoL studies have led to the development of numerous precise and multidimensional tools in recent years, so the choice of the appropriate method of an assessment and monitoring of QoL by the clinician or researcher should depend on the general patients' condition and the aim of the measurement. In everyday clinical practice an assessment and monitoring of QoL seem to be a necessity similarly to the evaluation of other live parameters.

One of the possibilities of screening the psychological state of cancer patients is a distress thermometer that on a scale from 0 to 10 indicates no stress (0) to the strongest psychological distress (10) (Fig. 1) [19, 20]. The results of 0-4 do not require further interventions. However, when the score equals 5 or more, patients are asked a series of questions which comprise different live dimensions, which aims to establish the cause of the stress (Fig. 2). Explanations from a person talking with a patient regarding the questionnaire filling might be useful. An additional screening tool for detecting psychological disturbances might be a Hospital Anxiety and Depression Scale (HADS) which was supplemented in the Polish version with two questions regarding anger [21].

For QoL assessment made once (conducted in the evening) or twice daily (performed in the morning and in the evening) for patients staying at in-patient units, an Edmonton Symptom Assessment System (ESAS) questionnaire is recommended. ESAS is a simple tool possessing good psychometric properties and can be filled in by the patient within a short time. Results obtained may be shown in a graphic form that resembles the temperature or heart rate plot measured in the morning and in the evening on consecutive days of a stay 
Fig. 6. The EORTC QLQ-CX24 questionnaire

Patients sometimes report that they have the following symptoms or problems. Please indicate the extent to which you have experienced these symptoms or problems, please answer by circling the number that best applies to you.

\begin{tabular}{|c|c|c|c|c|}
\hline During the past week: & $\begin{array}{c}\text { Not at } \\
\text { all }\end{array}$ & $\begin{array}{c}\text { A } \\
\text { little }\end{array}$ & $\begin{array}{l}\text { Quite } \\
\text { a bit }\end{array}$ & $\begin{array}{l}\text { Very } \\
\text { much }\end{array}$ \\
\hline 1. Have you had cramps in your abdomen? & 1 & 2 & 3 & 4 \\
\hline 2. Have you had difficulty in controlling your bowels? & 1 & 2 & 3 & 4 \\
\hline 3. Have you had blood in your stools (motions)? & 1 & 2 & 3 & 4 \\
\hline 4. Did you pass water/urine frequently? & 1 & 2 & 3 & 4 \\
\hline 5. Have you had pain or a burning feeling when passing water/urinating? & 1 & 2 & 3 & 4 \\
\hline 6. Have you had leaking of urine? & 1 & 2 & 3 & 4 \\
\hline 7. Have you had difficulty emptying your bladder? & 1 & 2 & 3 & 4 \\
\hline 8. Have you had swelling in one or both legs? & 1 & 2 & 3 & 4 \\
\hline 9. Have you had pain in your lower back? & 1 & 2 & 3 & 4 \\
\hline 10. Have you had tingling or numbness in your hands or feet? & 1 & 2 & 3 & 4 \\
\hline 11. Have you had irritation or soreness in your vagina or vulva? & 1 & 2 & 3 & 4 \\
\hline 12. Have you had discharge from your vagina? & 1 & 2 & 3 & 4 \\
\hline 13. Have you had abnormal bleeding from your vagina? & 1 & 2 & 3 & 4 \\
\hline 14. Have you had hot flushes and/or sweats? & 1 & 2 & 3 & 4 \\
\hline 15. Have you felt physically less attractive as a result of your disease or treatment? & 1 & 2 & 3 & 4 \\
\hline 16. Have you felt less feminine as a result of your disease or treatment? & 1 & 2 & 3 & 4 \\
\hline 17. Have you felt dissatisfied with your body? & 1 & 2 & 3 & 4 \\
\hline During the past week: & $\begin{array}{c}\text { Not at } \\
\text { all }\end{array}$ & $\begin{array}{c}\text { A } \\
\text { little }\end{array}$ & $\begin{array}{c}\text { Quite } \\
\text { a bit }\end{array}$ & $\begin{array}{l}\text { Very } \\
\text { much }\end{array}$ \\
\hline 18. Have you worried that sex would be painful? & 1 & 2 & 3 & 4 \\
\hline 19. Have you been sexually active? & 1 & 2 & 3 & 4 \\
\hline Answer these questions only if you have been sexually active during the past 4 weeks: & $\begin{array}{c}\text { Not at } \\
\text { all }\end{array}$ & $\begin{array}{c}\mathrm{A} \\
\text { little }\end{array}$ & $\begin{array}{c}\text { Quite } \\
\text { a bit }\end{array}$ & $\begin{array}{l}\text { Very } \\
\text { much }\end{array}$ \\
\hline 20. Has your vagina felt dry during sexual activity? & 1 & 2 & 3 & 4 \\
\hline 21. Has your vagina felt short? & 1 & 2 & 3 & 4 \\
\hline 22. Has your vagina felt tight? & 1 & 2 & 3 & 4 \\
\hline 23. Have you had pain during sexual intercourse or other sexual activity? & 1 & 2 & 3 & 4 \\
\hline 24. Was sexual activity enjoyable for you? & 1 & 2 & 3 & 4 \\
\hline
\end{tabular}

at an in-patient unit [22-25]. In patients in an ambulatory care setting, QoL assessment is conducted with the ESAS questionnaire during each patients' visit in an out-patient clinic and in home care, most often twice a week during nurses' visits.

For QoL assessment within clinical trials, a core questionnaire EORTC QLQ-C30 is conducted for patients during oncological treatment [26], which is supplemented with modules for given locations of the primary tumor e.g. cervical, ovary and endometrial cancer [27-29]. QoL assessment in patients using the aforementioned questionnaires is conducted most commonly every 7 days. An alternative tool might be the Rotterdam Symptom Checklist (RSCL) in which $A E$ of radiotherapy and chemotherapy are included [30]. In patients with advanced cancer under palliative care it is usually recommended to conduct the EORTC QLQC15-PAL questionnaire once a week. This questionnaire focuses mainly on physical symptoms and global QoL [31]. For the purpose of non-commercial clinical trials, EORTC questionnaires might be downloaded for free from the web page of the EORTC Quality of Life Group (http://groups.eortc.be/qol/).

\section{Selected quality of life assessment instruments for cancer patients}

\section{The Hospital Anxiety and Depression Scale (HADS)}

The questionnaire is devoted to screening of anxiety and depression in patients hospitalized in non-psychiatric departments. The original version of the tool consists of 7 questions regarding anxiety and 7 questions exploring depression. In a modified Polish version, 2 questions were added concerning irritability and aggression, which increased the usefulness of the tool as 
Fig. 7. The EORTC QLQ-OV28 questionnaire

Patients sometimes report that they have the following symptoms or problems. Please indicate the extent to which you have experienced these symptoms or problems during the past week.

\begin{tabular}{|c|c|c|c|c|}
\hline During the past week: & $\begin{array}{c}\text { Not at } \\
\text { all }\end{array}$ & $\begin{array}{c}\text { A } \\
\text { little }\end{array}$ & $\begin{array}{l}\text { Quite } \\
\text { a bit }\end{array}$ & $\begin{array}{l}\text { Very } \\
\text { much }\end{array}$ \\
\hline 1. Did you have abdominal pain? & 1 & 2 & 3 & 4 \\
\hline 2. Did you have a bloated feeling in your abdomen/stomach? & 1 & 2 & 3 & 4 \\
\hline 3. Did you have problems with your clothes feeling too tight? & 1 & 2 & 3 & 4 \\
\hline 4. Did you experience change in bowel habit as a result of your disease or treatment? & 1 & 2 & 3 & 4 \\
\hline 5. Were you troubled by passing wind/gas/flatulence? & 1 & 2 & 3 & 4 \\
\hline 6. Have you felt full up too quickly after beginning to eat? & 1 & 2 & 3 & 4 \\
\hline 7. Have you had indigestion or heartburn? & 1 & 2 & 3 & 4 \\
\hline 8. Have you lost any hair? & 1 & 2 & 3 & 4 \\
\hline Answer this question only if you had any hair loss: & $\begin{array}{c}\text { Not at } \\
\text { all }\end{array}$ & $\begin{array}{c}\text { A } \\
\text { little }\end{array}$ & $\begin{array}{l}\text { Quite } \\
\text { a bit }\end{array}$ & $\begin{array}{l}\text { Very } \\
\text { much }\end{array}$ \\
\hline 9. Were you upset by the loss of your hair? & 1 & 2 & 3 & 4 \\
\hline 10. Did food and drink taste different from usual? & 1 & 2 & 3 & 4 \\
\hline 11. Have you had tingling hands or feet? & 1 & 2 & 3 & 4 \\
\hline 12. Have you had numbness in your fingers or toes? & 1 & 2 & 3 & 4 \\
\hline 13. Have you felt weak in your arms or legs? & 1 & 2 & 3 & 4 \\
\hline 14. Did you have aches or pains in your muscles or joints? & 1 & 2 & 3 & 4 \\
\hline 15. Did you have problems with hearing? & 1 & 2 & 3 & 4 \\
\hline 16. Did you urinate frequently? & 1 & 2 & 3 & 4 \\
\hline 17. Have you had skin problems (e.g. itchy, dry)? & 1 & 2 & 3 & 4 \\
\hline 18. Did you have hot flushes? & 1 & 2 & 3 & 4 \\
\hline 19. Did you have night sweats? & 1 & 2 & 3 & 4 \\
\hline During the past week: & $\begin{array}{c}\text { Not at } \\
\text { all }\end{array}$ & $\begin{array}{c}\text { A } \\
\text { little }\end{array}$ & $\begin{array}{l}\text { Quite } \\
\text { a bit }\end{array}$ & $\begin{array}{l}\text { Very } \\
\text { much }\end{array}$ \\
\hline 20. Have you felt physically less attractive as a result of your disease or treatment? & 1 & 2 & 3 & 4 \\
\hline 21. Have you been dissatisfied with your body? & 1 & 2 & 3 & 4 \\
\hline 22. How much has your disease been a burden to you? & 1 & 2 & 3 & 4 \\
\hline 23. How much has your treatment been a burden to you? & 1 & 2 & 3 & 4 \\
\hline 24. Were you worried about your future health? & 1 & 2 & 3 & 4 \\
\hline During the past 4 week: & $\begin{array}{c}\text { Not at } \\
\text { all }\end{array}$ & $\begin{array}{c}\text { A } \\
\text { little }\end{array}$ & $\begin{array}{l}\text { Quite } \\
\text { a bit }\end{array}$ & $\begin{array}{l}\text { Very } \\
\text { much }\end{array}$ \\
\hline To what extent were you interested in sex? & 1 & 2 & 3 & 4 \\
\hline To what extent were you sexually active? & 1 & 2 & 3 & 4 \\
\hline \multicolumn{5}{|l|}{ Answer the following two questions only if you were sexually active: } \\
\hline To what extent was sex enjoyable for you? & 1 & 2 & 3 & 4 \\
\hline Did you have a dry vagina during sexual activity? & 1 & 2 & 3 & 4 \\
\hline
\end{tabular}

a separate method of exploration of patient's emotional reaction to the disease (Fig. 3). The tool is short, easy to use and interpret [21].

\section{European Organization for the Research and} Treatment of Cancer Quality of Life Questionnaire - Core 30 (EORTC QLQ-C30)

EORTC QLQ-C30 (Fig. 4) was elaborated by the Quality of Life Group of the European Organization for the Research and Treatment of Cancer (EORTC) as a core questionnaire and a part of the modular approach and multidimensional measurement of QoL in cancer patients [26]. A more precise QoL assessment depending on the location of the primary tumor may be conducted together with the EORTC QLQ-C30 or with the EORTC QLQ-C15-PAL (Fig. 5) module for patients with cervical cancer (EORTC QLQ-CX24) (Fig. 6), ovarian cancer (EORTC QLQ-OV28) (Fig. 7), and endometrial cancer (EORTC QLQ-EN24) (Fig. 8) adapted to Polish [27-29].

The EORTC QLQ-C30 contains questions about how the disease influences patients' functioning (functional scales) 
Fig. 8. The EORTC QLQ-EN24 questionnaire

Patients sometimes report that they have the following symptoms or problems. Please indicate the extent to which you have experienced these symptoms or problems.

\begin{tabular}{|c|c|c|c|c|}
\hline During the past week: & $\begin{array}{l}\text { Not at } \\
\text { all }\end{array}$ & $\begin{array}{c}\text { A } \\
\text { little }\end{array}$ & $\begin{array}{l}\text { Quite } \\
\text { a bit }\end{array}$ & $\begin{array}{l}\text { Very } \\
\text { much }\end{array}$ \\
\hline 1. Have you had swelling in one or both legs? & 1 & 2 & 3 & 4 \\
\hline 2. Have you felt heaviness in one or both legs? & 1 & 2 & 3 & 4 \\
\hline 3. Have you had pain in your lower back and/or pelvis? & 1 & 2 & 3 & 4 \\
\hline 4. When you felt the urge to pass urine, did you have to hurry to get to the toilet? & 1 & 2 & 3 & 4 \\
\hline 5. Have you passed the urine frequently? & 1 & 2 & 3 & 4 \\
\hline 6. Have you had leaking of urine? & 1 & 2 & 3 & 4 \\
\hline 7. Have you had pain or a burning feeling when passing urine? & 1 & 2 & 3 & 4 \\
\hline 8. When you felt the urge to pass your bowels, did you have to hurry to get to the toilet? & 1 & 2 & 3 & 4 \\
\hline 9. Have you had any leakage of stools? & 1 & 2 & 3 & 4 \\
\hline 10. Have you been troubled by passing wind? & 1 & 2 & 3 & 4 \\
\hline 11. Have you had cramps in your abdomen? & 1 & 2 & 3 & 4 \\
\hline 12. Have you had a bloated feeling in your abdomen? & 1 & 2 & 3 & 4 \\
\hline 13. Have you had tingling or numbness in your hands or feet? & 1 & 2 & 3 & 4 \\
\hline 14. Have you had aches or pains in your muscles or joints? & 1 & 2 & 3 & 4 \\
\hline 15. Have you lost hair? & 1 & 2 & 3 & 4 \\
\hline 16. Has food and drink tasted differently from usual? & 1 & 2 & 3 & 4 \\
\hline During the past week: & $\begin{array}{l}\text { Not at } \\
\text { all }\end{array}$ & $\begin{array}{c}\text { A } \\
\text { little }\end{array}$ & $\begin{array}{l}\text { Quite } \\
\text { a bit }\end{array}$ & $\begin{array}{l}\text { Very } \\
\text { much }\end{array}$ \\
\hline 17. Have you felt physically less attractive as a result of your disease or treatment? & 1 & 2 & 3 & 4 \\
\hline 18. Have you felt less feminine as a result of your disease or treatment? & 1 & 2 & 3 & 4 \\
\hline During the past 4 week: & $\begin{array}{l}\text { Not at } \\
\text { all }\end{array}$ & $\begin{array}{c}\text { A } \\
\text { little }\end{array}$ & $\begin{array}{l}\text { Quite } \\
\text { a bit }\end{array}$ & $\begin{array}{l}\text { Very } \\
\text { much }\end{array}$ \\
\hline 19. To what extent were you interested in sex? & 1 & 2 & 3 & 4 \\
\hline 20. To what extent were you sexually active? & 1 & 2 & 3 & 4 \\
\hline \multicolumn{5}{|l|}{$\begin{array}{l}\text { Answer these questions only if you have been sexually active during the past } \\
4 \text { weeks: }\end{array}$} \\
\hline 21. Has your vagina felt dry during sexual activity? & 1 & 2 & 3 & 4 \\
\hline 22. Has your vagina felt short and/or tight? & 1 & 2 & 3 & 4 \\
\hline 23. Have you had pain during sexual intercourse or other sexual activity? & 1 & 2 & 3 & 4 \\
\hline 24. Was sexual activity enjoyable for you? & 1 & 2 & 3 & 4 \\
\hline
\end{tabular}

and how symptoms impact patients' QoL (symptom scales). The functional scales comprise physical functioning, role functioning (work), emotional, cognitive and social functioning and global QoL. The symptom scales consist of fatigue, nausea and vomiting, and pain scales and single items of dyspnea, sleep disturbances, lack of appetite, constipation, diarrhea and the impact of the disease on finances. In the majority of questions of the EORTC QLQ-C30, a 4-step Likert scale is used; in 2 questions regarding health status and global QoL, a 7-step scale was used.

\section{European Organization for Research and}

Treatment of Concer Quality of Life Questionnaire - Core 15 - Palliative Care (EORTC QLQ-C15-PAL)

A shorter version of the EORTC QLQ-C30 questionnaire was elaborated, devoted to patients with advanced cancer, which comprises 15 questions (the EORTC QLQ(15-PAL) [31]. The EORTC QLQ-C15-PAL questionnaire was adapted to Polish [32].

\section{The Rotterdam Symptom Checklist (RSCL)}

The tool consists of 30 items regarding symptoms and 8 questions concerning patients' everyday activity (Fig. 9). Based on the factor analysis two dimensions were found: psychological and physical. The psychological factor is composed of irritability, worrying, depressed mood, nervousness, desperate feelings about the future, tension, anxiety and difficulty concentrating. For the physical factor all other items were included. RSCL comprises the impact of the cancer treatment on psychosocial functioning of patients and it is a valid (with appropriate validity and reliability) instrument for the as- 
Fig. 9. The Rotterdam Symptom Checklist (RSCL)

In this questionnaire you will be asked about your symptoms. Would you please, for all symptoms mentioned, indicate to what extent you have been bothered by it, by circling the answer most applicable to you. The questions are related to the past week. Example: Have you been bothered, during the past week, by

\begin{tabular}{|c|c|c|c|c|}
\hline headaches & not at all & a little & quite a bit & very much \\
\hline \multicolumn{5}{|c|}{ Have you, during the past week, been bothered by } \\
\hline lack of appetite & not at all & a little & quite a bit & very much \\
\hline irritability & not at all & a little & quite a bit & very much \\
\hline tiredness & not at all & a little & quite a bit & very much \\
\hline worrying & not at all & a little & quite a bit & very much \\
\hline sore muscles & not at all & a little & quite a bit & very much \\
\hline depressed mood & not at all & a little & quite a bit & very much \\
\hline lack of energy & not at all & a little & quite a bit & very much \\
\hline low back pain & not at all & a little & quite a bit & very much \\
\hline nervousness & not at all & a little & quite a bit & very much \\
\hline nausea & not at all & a little & quite a bit & very much \\
\hline desperate feelings about the future & not at all & a little & quite a bit & very much \\
\hline difficulties sleeping & not at all & a little & quite a bit & very much \\
\hline headaches & not at all & a little & quite a bit & very much \\
\hline vomiting & not at all & a little & quite a bit & very much \\
\hline dizziness & not at all & a little & quite a bit & very much \\
\hline decreased sexual interest & not at all & a little & quite a bit & very much \\
\hline tension & not at all & a little & quite a bit & very much \\
\hline abdominal (stomach) aches & not at all & a little & quite a bit & very much \\
\hline anxiety & not at all & a little & quite a bit & very much \\
\hline constipation & not at all & a little & quite a bit & very much \\
\hline diarrhea & not at all & a little & quite a bit & very much \\
\hline acid indigestion & not at all & a little & quite a bit & very much \\
\hline shivering & not at all & a little & quite a bit & very much \\
\hline tingling hands or feet & not at all & a little & quite a bit & very much \\
\hline difficulty concentrating & not at all & a little & quite a bit & very much \\
\hline sore mouth/pain when swallowing & not at all & a little & quite a bit & very much \\
\hline loss of hair & not at all & a little & quite a bit & very much \\
\hline burning/sore eyes & not at all & a little & quite a bit & very much \\
\hline shortness of breath & not at all & a little & quite a bit & very much \\
\hline dry mouth & not at all & a little & quite a bit & very much \\
\hline
\end{tabular}

A number of activities is listed below. We do not want to know whether you actually do these, but only whether you are able to perform them presently.

Would you please mark the answer that applies most to your condition of the past week.

\begin{tabular}{lcccc}
\hline & Unable & $\begin{array}{c}\text { Only with } \\
\text { help }\end{array}$ & $\begin{array}{c}\text { Without help, } \\
\text { with difficulty }\end{array}$ & Without help \\
\hline care for myself (wash etc.) & 0 & 0 & 0 & 0 \\
\hline walk about the house & 0 & 0 & 0 & 0 \\
\hline light housework/household jobs & 0 & 0 & 0 & 0 \\
\hline climb stairs & 0 & 0 & 0 & 0 \\
\hline heavy housework/household jobs & 0 & 0 & 0 & 0 \\
\hline walk out of doors & 0 & 0 & 0 & 0 \\
\hline go shopping & 0 & 0 & 0 & 0 \\
\hline go to work & 0 & 0 & 0 & 0 \\
\hline
\end{tabular}

All things considered, how would you describe your quality of life during the past week?

0 excellent

0 good

0 moderately good

0 neither good nor bad

0 rather poor

0 poor

0 extremely poor

Would you please check whether you answered all questions?

Thank you for your help. 
Fig. 10. The Modified Edmonton Symptom Assessment System (revised version) (ESAS-r)

Please circle the number that best describes:

\begin{tabular}{|c|c|c|c|c|c|c|c|c|c|c|}
\hline No pain & 1 & 2 & 3 & 4 & 5 & 6 & 7 & 89 & 10 & Worst possible pain \\
\hline Not tired & 1 & 2 & 3 & 4 & 5 & 6 & 7 & 89 & 10 & Worst possible tiredness \\
\hline Not nauseated & 1 & 2 & 3 & 4 & 5 & 6 & 7 & 89 & 10 & Worst possible nausea \\
\hline No vomiting & 1 & 2 & 3 & 4 & 5 & 6 & 7 & 89 & 10 & Worst possible vomiting \\
\hline No constipation & 1 & 2 & 3 & 4 & 5 & 6 & 7 & 89 & 10 & Worst possible constipation \\
\hline Not depressed & 1 & 2 & 3 & 4 & 5 & 6 & 7 & 89 & 10 & Worst possible depression \\
\hline Not anxious & 1 & 2 & 3 & 4 & 5 & 6 & 7 & 89 & 10 & Worst possible anxiety \\
\hline Not drowsy & 1 & 2 & 3 & 4 & 5 & 6 & 7 & 89 & 10 & Worst possible drowsiness \\
\hline Best appetite & 1 & 2 & 3 & 4 & 5 & 6 & 7 & 89 & 10 & Worst possible appetite \\
\hline Best feeling of wellbeing & 1 & 2 & 3 & 4 & 5 & 6 & 7 & 89 & 10 & Worst possible feeling of wellbeing \\
\hline No shortness of breath & 1 & 2 & 3 & 4 & 5 & 6 & 7 & 89 & 10 & Worst possible shortness of breath \\
\hline Other problem & 1 & 2 & 3 & 4 & 5 & 6 & 7 & 8 & 10 & \\
\hline \multicolumn{11}{|c|}{ Patient Name } \\
\hline Date & & & ime & & & & & & & \\
\hline
\end{tabular}

sessment of psychological, social, professional and physical domains of patients' QoL [30].

\section{Edmonton Symptom Assessment System (ESAS)}

Edmonton Symptom Assessment System in the original version is composed of 10 visual-analogue scales, depicted on the left as the least intensity or lack of a symptom and at the right as the most severe intensity of a symptom. The patient marks in her opinion the most appropriate place on the scale of pain, activity, nausea, depression, anxiety, drowsiness, appetite, well-being, dyspnea, and one additional symptom mentioned by the patient [22]. In the Polish modified version, two frequent symptoms encountered in palliative care patients were added: constipation and vomiting (Fig. 10). ESAS may be filled in in a few minutes; it may be conducted in hospital departments mostly twice daily. ESAS is a validated tool with appropriate validity and reliability. The currently recommended version of the ESAS is the so called ESAS-revised (ESAS-r), which compared to the original version contains fatigue instead of activity; the evaluation is conducted using numerical scales from 0 (lack of a symptom) to 10 (the most severe symptom intensity [23].

\section{Conclusions}

QoL evaluation makes it possible to obtain important information from patients regarding not only symptoms of the disease, $A E$ of the treatment but also psychological, social and spiritual dimensions. QoL assessment conducted in gynecological cancer patients should take into account many burdensome symptoms, which negatively influence patients' QoL. The instruments used should be short and easy to under- stand and those conducting the evaluation should pay attention to clinical staging of the patients. Apart from everyday clinical practice, QoL assessment is a significant part of clinical trials and a source of progress in the oncological treatment and symptomatic management of cancer. One of the important aims of cancer management is improvement and maintenance of the highest QoL possible in cancer patients, especially in those with advanced disease and in their families and carers.

\section{Disclosure}

Authors report no conflict of interest.

\section{References}

1. Shipper H. Quality of life. Principles of the clinical paradigm. J Psychol Oncol 1990; 8: 171-185.

2. Aaronson NK, Cull A, Kaasa S, et al. Modułowe postępowanie Europejskiej Organizacji do Badań i Leczenia Raka (EORTC) do oceny jakości życia chorych na nowotwory. Modyfikacja. In: Jakość życia w chorobie nowotworowej. Meyza J (ed.). Centrum Onkologii, Warszawa 1997; pp. 13-36.

3. Brzeziński J. Metodologiczny i etyczny kontekst badań nad jakością życia. In: Psychologiczne i pedagogiczne wymiary jakości życia. Bańka A, Derbis R (eds.). UAM Poznań i WSP, Częstochowa 1994; pp. 11-18.

4. Calman KC. Quality of life in cancer patients - an hypothesis. J Med Ethics 1984; 10: 124-127.

5. De Walden Gałuszko K. Jakość życia - rozważania ogólne. In: Jakość życia w chorobie nowotworowej. De Walden Gałuszko K, Majkowicz M. Wydawnictwo Uniwersytetu Gdańskiego 1994, pp. 13-40.

6. Majkowicz M. Wielopoziomowa ocena stanu podmiotowego pacjentów z chorobą nowotworową. Rozprawa habilitacyjna. Akademia Medyczna, Gdańsk 2005. Ann Acad Med Ged 2005; 35 Suppl. 2.

7. National Comprehensive Cancer Network. Clinical Practice Guidelines in Oncology Ovarian cancer including Fallopian tube cancer and primary peritoneal cancer. V. 3.2014. http://www.nccn.org/professionals/physician_gls/f_guidelines.asp\#ovarian. Access 18.09.2015.

8. Ledermann JA, Raja FA, Fotopoulou C, et al. Newly diagnosed and relapsed epithelial ovarian carcinoma: ESMO Clinical Practice Guidelines for diagnosis, treatment and follow-up. Ann Oncol 2013; 24 (Suppl 6): vi24-vi32. 
9. Dobrowolska M. Wybrane zasoby psychologiczne pacjentek chorych na raka jajnika a stopień skutków ubocznych chemioterapii. Psychoonkologia 2013; 17: 56-61.

10. Muszyńska-Wiese E, Wilkoszarska J. Jakość życia kobiet chorych na raka jajnika. In: Rak jajnika. Markowska J (ed.). Springer PWN, Warszawa 1997; pp. 183-188.

11. National Comprehensive Cancer Network. Clinical Practice Guidelines in Oncology Cervical cancer. V. 1.2015. http://www.nccn.org/professionals/physician_gls/pdf/cervical.pdf. Access 18.09.2015.

12. Colombo N, Carinelli S, Colombo A, et al. Cervical cancer: ESMO Clinical Practice Guidelines for diagnosis, treatment and follow-up. Ann Oncol 2012; 23 (Suppl 7): vii27-vii32.

13. National Comprehensive Cancer Network. Clinical Practice Guidelines in Oncology Uterine neoplasms. V. 1.2015. http://www.nccn.org/professionals/physician_gls/f_guidelines.asp\#uterine. Access 18.09.2015.

14. Colombo N, Preti E, Landoni F, et al. Endometrial cancer: ESMO Clinical Practice Guidelines for diagnosis, treatment and follow-up. Ann Oncol 2013; 24 (Suppl 6): vi33-vi38.

15. Bidzan M, Rudnik A, Peplińska A. Korelaty pomiędzy różnymi obszarami życia kobiet po operacji raka szyjki macicy metodą Wertheima-Meigsa w odniesieniu do jakości życia. Psychoonkologia 2013; 17: 62-70.

16. Piekarski J, Jareczek-Fossa B, Nejc D, et al. Does fecal diversion offer any chance for spontaneous closure of the radiation induced rectovaginal fistula? Int J Gynecol Cancer 2008; 18: 66-70.

17. Di Donato V, Bellati F, Fischetti M, et al. Vaginal cancer. Crit Rev Oncol Hematol 2012; 81: 286-295

18. Woelber L, Kock L, Gieseking F, et al. Clinical management of primary vulvar cancer. Eur J Cancer 2011; 47: 2315-2321.

19. Grassi L, Johansen C, Annunziata MA, et al.; Italian Society of PsychoOncology Distress Thermometer Study Group. Screening for distress in cancer patients: a multicenter, nationwide study in Italy. Cancer 2013; 119: 1714-1721.

20. www.ptpo.org.pl. Access 18.09.2015.

21. Zigmond AS, Snaith RP. The hospital anxiety and depression (HAD) scale. Acta Psychiatr Scan 1983; 67: 361-370.

22. Bruera E, Kuehn N, Miller MJ, et al. The Edmonton Symptom Assessment System (ESAS): a simple method for the assessment of palliative care patients. J Palliat Care 1991; 7: 6-9.
23. Watanabe SM, Nekolaichuk C, Beaumont C, et al. A multicenter study comparing two numerical versions of the Edmonton Symptom Assessment System in palliative care patients. J Pain Symptom Manage 2011; 41: 456-468.

24. De Walden-Gałuszko K, Majkowicz M. Model oceny jakości opieki paliatywnej realizowanej w warunkach stacjonarnych. Akademia Medyczna, Gdańsk. Zakład Medycyny Paliatywnej, Gdańsk 2001.

25. De Walden-Gałuszko K, Majkowicz M. Model oceny jakości opieki paliatywnej realizowanej w warunkach ambulatoryjnych. Akademia Medyczna, Gdańsk. Zakład Medycyny Paliatywnej, Gdańsk 2000.

26. Aaronson NK, Ahmedzai S, Bergman B, et al. The European Organization for Research and Treatment of Cancer QLQ-C30: a quality-of-life instrument for use in international clinical trials in oncology. J Natl Cancer Institute 1993; 85: 365-376.

27. Paradowska D, Tomaszewski KA, Bałajewicz-Nowak M, et al. Validation of the Polish version of the EORTC QLQ-CX24 module for the assessment of health-related quality of life in women with cervical cancer. Eur J Cancer Care 2014; 23: 214-220.

28. Paradowski J, Tomaszewski KA, Bereza K, et al. Validation of the Polish version of the EORTC QLQ-OV28 module for the assessment of healthrelated quality of life in women with ovarian cancer. Expert Rev Pharmacoecon Outcomes Res 2014; 14: 157-163.

29. Stukan M, Zalewski K, Grabowski JP, et al. Creation of the Polish version and adaptation of the European Organization for Research and Treatment of Cancer Quality of Life Questionnaire-Endometrial Cancer Module (QLQ-EN24). Współcz Onkol 2014; 18: 134-139.

30. De Haes JCM, van Knippenberg FCE, Nejt JP. Measuring psychological and physical distress in cancer patients: structure and application of the Rotterdam Symptom Checklist. Br J Cancer 1990; 62: 1034-1038.

31. Groenvold M, Petersen MA, Aaronson NK, et al.; for the EORTC Quality of Life Group. The development of the EORTC QLQ-C15-AL: a shortened questionnaire for cancer patients in palliative care. Eur J Cancer 2006; 42: 55-64.

32. Leppert W, Majkowicz M. Validation of the Polish version of the European Organization for Research and Treatment of Cancer Quality of Life Questionnaire-Core15-Palliative Care (EORTC QLQ-C15-PAL) in patients with advanced cancer. Palliat Med 2013; 27: 470-477. 